Check for updates

Cite this: RSC Adv., 2019, 9, 28618

\title{
Feasibility of advancing the development of compact energy systems $\uparrow$
}

\begin{abstract}
Sampath Gunukula, (D) Ivan C. Lee and Dat T. Tran*
It is necessary to advance the development of compact energy systems for making energy from biomass like wood or switchgrass, as an alternative to the construction of highly capital-intensive large scale biorefineries. Compact energy systems consist of four individual components: a biomass preparation unit, a biomass converter, a fuel processor, and a powered engine. The individual unit processes within each component and the possible types of compact energy systems with different biomass converter technologies like fermentation, pyrolysis, and gasification are presented. The size, weight, and energy efficiency of upgrading biomass to energy using a compact energy system with various gasification technologies has been estimated. A compact energy system with a hydrogen fuel cell as a poweredengine component, processing $10 \mathrm{~kg}$ of dry biomass per day, generates a net energy ( $\mathrm{kW} h$ ) of -7.5 , $-30,18.7,13.1$, and 11.7 with the super-critical, microwave assisted, catalytic, steam, and conventional gasification technologies as biomass converter technologies, respectively. The low yields of super-critical gasification and low efficacy of converting electric energy to heat via electromagnetic waves with microwave assisted gasification result in negative net energy with the respective compact energy system. Finally, the challenges and opportunities with the development of low weight, small size, and highly energy efficient compact energy systems built around gasification are discussed.
\end{abstract}

Received 3rd August 2019

Accepted 5th September 2019

DOI: 10.1039/c9ra06039a

rsc.li/rsc-advances density of biomass is inherently very low. ${ }^{4}$ It is recently shown that the biomass densification using palletization, torrefaction, and pyrolysis to overcome the logistic issues is not economically viable. $^{5}$

The limitations of fuel production in a large scale biorefinery facility can be addressed by developing compact energy systems with an arbitrary biomass processing capacity ranging anywhere between $1 \mathrm{~kg}$ and $100 \mathrm{~kg}$ per day. The biomass to make fuels using compact energy systems can be obtained from household generated food, yard, and plastic wastes. Compact energy systems would thus eliminate the difficulty of transporting large quantities of biomass to bio refinery locations. Furthermore, these compact energy systems can be manufactured by smaller specialized shops and thus the construction of large scale biorefineries would no longer be required. Additionally, the use of the food and plastic waste as a feedstock eliminates the costs of collecting, transporting, and landfilling these wastes. Compact energy systems can be used as an in-built (or on-board) power source for manned and unmanned vehicles or as an independent power source for recharging purposes. In both applications, the net available energy of a compact energy system, which is defined as the specific higher heating value of the fuel product minus the sum of total energy input to upgrade biomass to the fuel product, must be positive. Moreover, the physical dimensions of compact energy systems for on-board applications must meet the weight and footprint (volume) requirements of manned and unmanned vehicles.
CCDC Army Research Laboratory, FCDD-RLS-DE, Adelphi, MD, 20783, USA. E-mail: dat.t.tran4.civ@mail.mil

$\dagger$ Electronic supplementary information (ESI) available. See DOI: 10.1039/c9ra06039a 
The development of a compact energy system dates to the World War II. ${ }^{6}$ During the wartime, several European nations produced a wood gas vehicle with an on-board fuel generation system. These on-board fuel generation systems gasified wood to make energy. After World War II, on-board fuel generation technology fell into oblivion because of its heavy weight, low energy efficiency, and large size (footprint). In recent times, a great amount of research has been dedicated towards the development of a wide range of new biomass conversion pathways as well as compact thermoelectric devices like Stirling engine and electrochemical devices like fuel cells. Such research efforts will enable us to build new compact energy systems with a small size, low weight, and high energy efficiency.

There are 15 different types of compact energy systems that can be built using gasification as a biomass conversion pathway (refer to Sections 2 and 3 of this study). Likewise, many compact energy systems can be built with fermentation and pyrolysis as the biomass conversion pathway (refer Section 2 of this study). To avoid potential losses to the research and development (R\&D) costs and to accelerate the commercialization of compact energy systems, R\&D efforts must be directed towards the development of feasible compact energy systems that can provide positive net available energy and meet the size and weight requirements. To this end, in this study, modeling analysis is performed to evaluate the feasibility of developing compact energy systems built around the biomass gasification pathway. Further, the challenges and research opportunities in the development of these types of compact energy systems are discussed.

\section{Major components of compact energy systems}

Fig. 1 outlines the four major components of compact energy system and they are biomass preparation unit, biomass converter, fuel processer, and fuel powered-engine. The biomass preparation component modifies the physical properties, like size, as well as the moisture content of incoming biomass in order to meet the inlet feedstock specifications of the biomass converter component. The biomass converter upgrades a low-energy density biomass (10 to $20 \mathrm{MJ}$ per $\mathrm{kg}$ ) to a high energy density fuel intermediate (30 to $40 \mathrm{MJ}$ per $\mathrm{kg}$ ). The fuel processor converts a high energy density fuel intermediate to the useful form of energy that meets the input specifications of the powered-engine component. Following paragraphs provide details of each component.

\subsection{The biomass preparation component}

The biomass preparation component contains multiple subcomponents. The type and number of sub-components are dependent upon the nature of the receiving biomass and the input feedstock specifications for the biomass converter. If, for instance, the receiving biomass is a lignocellulosic feedstock with a moisture content of around $30 \mathrm{wt} \%$ and the biomass converter uses thermochemical technology that operates with a feedstock moisture content of $10 \mathrm{wt} \%$, the sub-components of the biomass preparation component must include a dryer to reduce the moisture content of incoming biomass to $10 \mathrm{wt} \%$.

The possible sub-components of the biomass preparation component include, but are not limited to, any of these unit processes: mechanical screening, drying, grinding, and the physical, chemical, and mechanical pretreatment of a biomass. The mechanical screening of incoming biomass removes unwanted coarse particles. A dryer reduces the biomass moisture to the target level by evaporating water. The biomass size can be reduced with hammer mill type grinders. The lignocellulosic structure of a biomass can be disrupted by means of physical, chemical, and mechanical biomass pretreatment technologies so that the enzymes can access cellulose and hemicellulose of a biomass to produce fuel intermediates. ${ }^{7}$ It must be noted that the increase in number of unit processes within the biomass preparation component increases the total weight and volume of a compact energy system and decrease its energy efficiency.

\subsection{The biomass converter}

The biomass converter component upgrades biomass received from the biomass preparation component to a high energy density fuel intermediate. Biomass converters employ biomass conversion technologies like gasification, pyrolysis, and microbial fermentation or digestion. Gasification involves simple heating of a biomass to a high temperature in the presence of a limited oxygen. ${ }^{6}$ Gasification is further divided to conventional gasification, supercritical water gasification, steam gasification, catalytic gasification, and microwave assisted gasification. ${ }^{9}$ The details of these gasification technologies can be found in Pereira et al. ${ }^{9}$ The major product of biomass gasification is syngas (a mixture of $\mathrm{CO}, \mathrm{H}_{2}$, and a small amount of $\mathrm{CO}_{2}$ ). The composition and lower heating value of syngas, ranging between $2-15 \mathrm{MJ} \mathrm{Nm}^{-3}$, vary with the type of gasification and biomass composition. ${ }^{9}$

Like gasification, pyrolysis involves simple heating of a biomass. Pyrolysis, however, heats the biomass at lower temperatures without the presence of oxygen. Pyrolysis is further classified to auto pyrolysis, fast pyrolysis, catalytic fast pyrolysis, slow pyrolysis, and microwave assisted pyrolysis. ${ }^{\mathbf{1 0}}$ The major product of biomass slow pyrolysis operating at a temperature between 300 to $350{ }^{\circ} \mathrm{C}, 1 \mathrm{~atm}$, and a residence time of several hours is bio-char. ${ }^{10}$ Unlike slow pyrolysis, the other pyrolysis processes involve heating biomass to a higher temperature at a high rapid rate. Pyrolyzing biomass at a temperature between 500 to $550{ }^{\circ} \mathrm{C}, 1 \mathrm{~atm}$, and a residence time of less than 30 seconds produces bio-oil as a major product. ${ }^{10}$

The microbial technologies can synthesize liquid as well as gaseous fuels from carbohydrates, $\mathrm{CO}_{2}$, and organic wastes. The sugars derived from the decomposition of cellulose, hemicellulose, and starch can be transformed to a range of molecules including ethanol, acetone, propanol, and butanol using biosynthetic pathways in microorganisms like Saccharomyces cerevisiae and Escherichia coli. ${ }^{\mathbf{1 1 , 1 2}}$ Contrary to carbohydrate fermentation, algae can make biodiesel (alkyl esters of long 


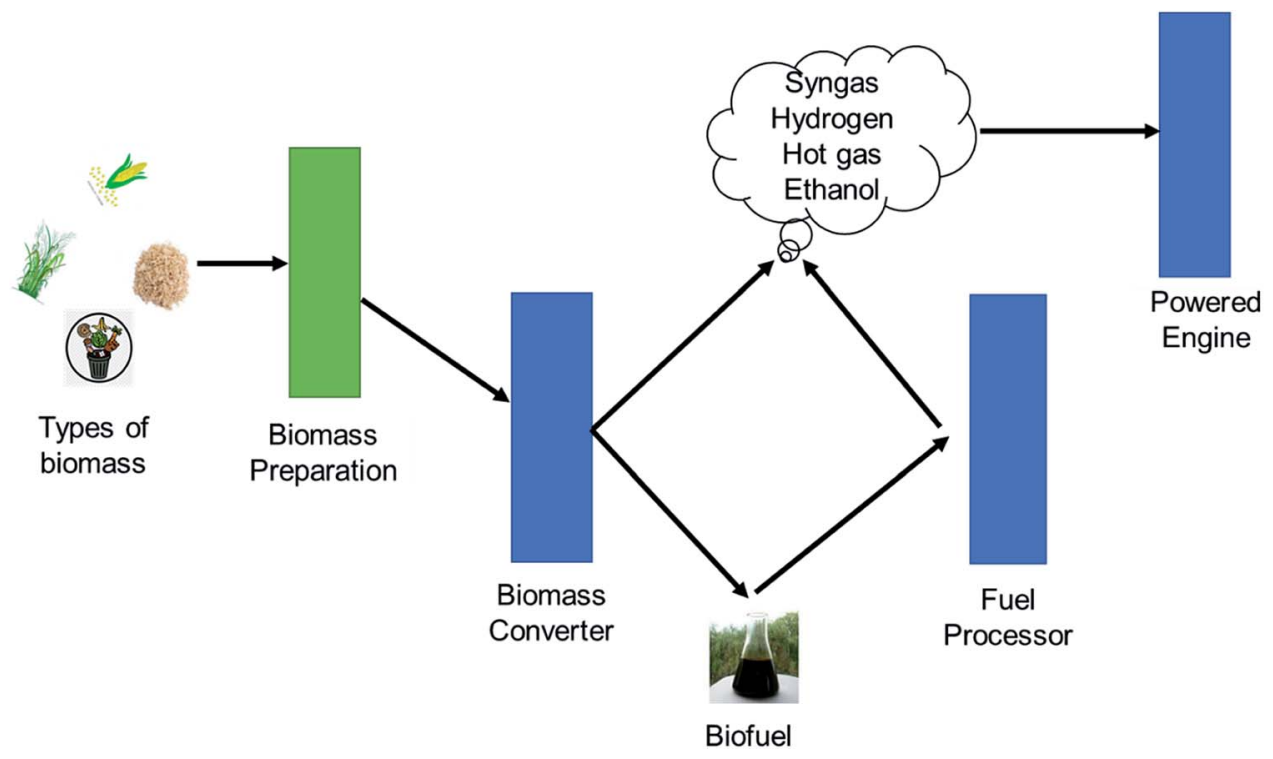

Fig. 1 Conceptual framework of the compact energy system.

chain fatty acids) by fixing $\mathrm{CO}_{2}$ from the atmosphere. ${ }^{12}$ The methanogenic decomposition of organic wastes can produce biogas, a mixture of $\mathrm{CH}_{4}$ and $\mathrm{CO}_{2}{ }^{12}$

The choice of a biomass converter technology influences the selection of sub-components of the biomass preparation unit as the biomass must meet certain specifications like size and moisture content specific to the biomass upgrading technology. If, for instance, a microbial technology is selected as a biomass converter, the biomass preparation unit must have subcomponents to process incoming biomass to fermentable sugars. The biomass preparation component must reduce the size of incoming biomass to $2 \mathrm{~mm}$ if gasification and pyrolysis technologies are deployed in the biomass converter.

\subsection{The fuel processor}

The fuel processor component has two sub-components: separation and fuel upgrading. The separation sub-component removes impurities from the product stream of either the biomass converter process or the fuel upgrading process to fulfill the purity requirements of the fuel upgrading subcomponent and powered-engine component, respectively. In the fuel upgrading sub-component, fuel upgrading technologies like combustion and steam reformers are employed to meet the feed requirements of a powered-engine component. For instance, if the powered-engine component uses a fuel cell and the biomass converter employs gasification, the fuel processor component must have a steam reformer as the fuel upgrading technology with a combined pressure swing adsorption and Pdmembrane as the separation technology, all operating at temperatures greater than $300{ }^{\circ} \mathrm{C}$. Here, the steam reformer enriches the amount of hydrogen in the syngas ${ }^{13}$ and the combined pressure swing adsorption and Pd-membrane removes impurities in the reformed syngas to make pure hydrogen, meeting the input specifications of the fuel cell. ${ }^{14,15}$

\subsection{The powered-engine}

The powered-engine component of compact energy systems use fuel delivered from the fuel processor component and convert that fuel to either mechanical or electrical energy. The powered-engine component can have a fuel cell, Stirling engine, or gas engine. ${ }^{16-18}$ While pure hydrogen is required as a feedstock for the fuel cell, sterling and gas engines can operate with impure hot gases. ${ }^{16-18}$

2.4.1 Energy storage module. In addition to the four major components, the compact energy system does have an energy storage module. In this module, energy can be stored in solid, liquid, or gaseous forms. The energy storage module can be integrated to any one of the four major components of a compact energy system. The form of energy storage and the location of the energy storage module are governed by the type and application of the compact energy system. Consider a compact energy system used for energy storage with a gasification process as the biomass converter and a fuel cell as the powered-engine technology. For this system and application, the energy storage module consists of a compressed tank and is integrated to the powered-engine component of the compact energy system. In another instance, a compact energy system with gasification and gas engine technologies designed for onboard energy application, the energy storage module contains a tank that can store biomass like wood; the tank can be integrated to the biomass preparation component.

\subsection{Possible combinations of energy components}

The different types of compact energy systems that can be built around pyrolysis, gasification, and fermentation technologies are presented in Tables 1, 2, and 3, respectively. These compact energy systems can make energy using lignocellulose feedstock and organic wastes. The lignocellulose feedstock can be tree bark, leaves, grass, corn stover, sugar cane bagasse, and other agricultural residues that are rich in lignin, cellulose, and 
Table 1 Different types of compact energy systems built around pyrolysis

\begin{tabular}{lllll}
\hline Feedstock & Biomass prep. & Biomass converter & Fuel processor & Powered-engine \\
\hline Lignocellulose/organic waste & Dryer and grinder & $\begin{array}{l}\text { Fast, auto, catalytic, or } \\
\text { microwave assisted pyrolysis }\end{array}$ & $\begin{array}{l}\text { Steam refining and char } \\
\text { separations } \\
\text { Steam refining and char }\end{array}$ & $\begin{array}{l}\text { Compressed tank and fuel } \\
\text { cell } \\
\text { Gas engine or Stirling engine }\end{array}$ \\
Lignocellulose/organic waste & Dryer and grinder & $\begin{array}{l}\text { Fast, auto, catalytic, or } \\
\text { microwave assisted pyrolysis }\end{array}$ & $\begin{array}{l}\text { separations } \\
\text { Combustion }\end{array}$ & Gas engine or Stirling engine \\
Lignocellulose/organic waste & Dryer and grinder & Slow pyrolysis & Direct carbon fuel cell \\
Lignocellulose/organic waste & Dryer and grinder & Slow pyrolysis & Gas engine or Stirling engine \\
Lignocellulose/organic waste & Dryer and grinder & $\begin{array}{l}\text { Fast, auto, catalytic, or } \\
\text { microwave assisted pyrolysis }\end{array}$ & $\begin{array}{l}\text { Blue whirl combustion and } \\
\text { separations }\end{array}$ & Solid oxide fuel cell \\
Lignocellulose/organic waste & Dryer and grinder & Fauto, catalytic, or \\
& & & &
\end{tabular}

hemicellulose. The organic waste consisting of food and plastic generated at household and industry levels, as well as its source of generation, greatly influence its composition. The moisture content of lignocellulosic feedstock is between $20 \mathrm{wt} \%$ and $50 \mathrm{wt} \%$. The moisture content of food waste is between $50 \mathrm{wt} \%$ and $90 \mathrm{wt} \%$. Because of the high moisture content of food waste, it can only be used with processes that operate under dilute conditions. Examples include microbial technologies and super critical gasification. These processes can use food waste because the evaporation of a high quantity of water consumes a large amount of energy.

Developing and deploying compact energy systems requires answering the following engineering and science questions:

(1) What are the ideal combinations of biomass preparation, biomass converter, fuel processor, and powered-engine technologies that are optimize energy efficiency, volume, and weight for the desired application?

(2) How does the target energy demand and potential application influence ideal combinations?

(3) What are the major technological barriers in developing the ideal compact energy system?

(4) In which form (solid biomass, liquid fuel intermediate like bio-oil and ethanol, or gaseous hydrogen) must the energy be stored in for potential use?
(5) What are the best types of biomass feedstocks that are suitable for compact energy systems?

(6) How much energy is required to acquire biomass feedstock and process it using different types of compact energy systems?

(7) How adaptable are these compact energy systems for the feedstock uncertainty?

In this study, we addressed most of these questions for compact energy systems built around gasification (Table 2) through a system modeling approach.

\section{The systems modeling of compact energy systems}

The general schematics of compact energy systems built around gasification was created and can be seen in Fig. 2. Table 4 lists different compact energy system types $\left(T_{n}\right.$, where $n$ is equal to 1 to 9) with necessary unit processes in each individual component. The unit processes in the biomass preparation unit, biomass converter, and fuel processor of the system were simulated using the ASPEN Plus and SuperPro Designer software to determine the size, energy, and weight requirements. The powered-engine component was modeled using empirical equations. The $\mathrm{ESI}_{\dagger} \dagger$ provides the details of system modeling.

Table 2 Different types of compact energy systems built around gasification

\begin{tabular}{|c|c|c|c|c|}
\hline Feedstock & $\begin{array}{l}\text { Biomass preparation } \\
\text { component }\end{array}$ & Biomass converter & Fuel processor & Powered-engine \\
\hline Lignocellulose & Dryer and grinder & Conventional gasification & $\begin{array}{l}\text { Steam refining and } \\
\text { separations }\end{array}$ & $\begin{array}{l}\text { Compressed tank and fuel } \\
\text { cell }\end{array}$ \\
\hline Lignocellulose & Grinder & Steam gasification & $\begin{array}{l}\text { Steam refining and } \\
\text { separations }\end{array}$ & $\begin{array}{l}\text { Compressed tank and fuel } \\
\text { cell }\end{array}$ \\
\hline Organic (food) waste & Grinder & $\begin{array}{l}\text { Supercritical water } \\
\text { gasification }\end{array}$ & $\begin{array}{l}\text { Steam refining and } \\
\text { separations }\end{array}$ & $\begin{array}{l}\text { Compressed tank and fuel } \\
\text { cell }\end{array}$ \\
\hline Lignocellulose & Dryer and grinder & $\begin{array}{l}\text { Microwave assisted catalytic } \\
\text { gasification }\end{array}$ & $\begin{array}{l}\text { Steam refining and } \\
\text { separations }\end{array}$ & $\begin{array}{l}\text { Compressed tank and fuel } \\
\text { cell }\end{array}$ \\
\hline $\begin{array}{l}\text { Lignocellulose and/or food } \\
\text { waste }\end{array}$ & Dryer and/or grinder & Gasification $^{a}$ & & $\begin{array}{l}\text { Gas engine or Stirling } \\
\text { engine }\end{array}$ \\
\hline
\end{tabular}

${ }^{a}$ Gasification can be conventional, steam, catalytic, supercritical, and microwave assisted. 
Table 3 Different types of compact energy systems built around fermentation

\begin{tabular}{|c|c|c|c|c|}
\hline Feedstocks & Biomass prep. & Biomass converter & Fuel processor & Powered-engine \\
\hline $\begin{array}{l}\text { Lignocellulose and/or food } \\
\text { waste }\end{array}$ & Grinder & $\begin{array}{l}\text { Enzymatic hydrolysis and } \\
\text { fermentation to make } \\
\text { biofuel }\end{array}$ & $\begin{array}{l}\text { Steam refiner and } \\
\text { separations }\end{array}$ & $\begin{array}{l}\text { Compressed tank and fuel } \\
\text { cell }\end{array}$ \\
\hline $\begin{array}{l}\text { Lignocellulose and/or food } \\
\text { waste }\end{array}$ & Grinder & $\begin{array}{l}\text { Enzymatic hydrolysis and } \\
\text { fermentation to make } \\
\text { ethanol }\end{array}$ & & $\begin{array}{l}\text { Ethanol or solid oxide fuel } \\
\text { cell }\end{array}$ \\
\hline
\end{tabular}

For the base case scenario, the dry biomass processing capacity of $10 \mathrm{~kg}$ per day was assumed.

\subsection{Size, weight, and efficiency analysis}

The results of the amount of hydrogen/producer gas made with compact energy systems built around biomass gasification as well as net energy, size, and weight requirements are presented in Table 5. Since gas and Stirling engines can be run with producer gas (syngas), separation and purification of hydrogen were not considered in T1, T2, T4, T5, T7, T8, T10, T11, T13 and T14 compact energy systems as these systems contain gas or Stirling engine powered-components. The moisture contents of biomass vary with compact energy system type because the optimal moisture of biomass that maximizes hydrogen yield or the heating value of syngas varies with the type of biomass gasification technology.

The use of food waste cannot be used in compact energy systems built around gasification. Given the high moisture content of food waste, only supercritical gasification seems a viable technology for the conversion of food waste to hydrogen or producer gas, as there is no need to evaporate a large quantity of water. However, the energy analysis has shown that the net energy generation is negative in compact energy systems built around supercritical gasification (T10, T11, and T12 in Table 3). Such high energy inefficiency is attributed to the low hydrogen yield with the T12 compact energy system and a low gross calorific value of producer gas with $\mathrm{T} 10$ and $\mathrm{T} 12$ systems. The size and weight requirements of compact energy systems built around supercritical gasification processes are found to be comparable to that of other types of compact energy systems.

The energy efficiency analysis of compact energy systems built around microwave assisted gasification (T13, T14, and T15) has indicated that the energy generated from biomass is not enough to meet the energy demand of upgrading biomass to hydrogen or producer gas. This is due to the low efficiency of converting electric energy to heat via electromagnetic waves. The efficiency of converting from electrical energy to electromagnetic waves (microwaves) using magnetrons built into the microwave reactor is about $50 \% .^{2}$ An absorbent must be placed in a microwave reactor to absorb heat from electromagnetic waves generated by the magnetron. ${ }^{1}$ The efficiency of converting microwaves to heat depends on the dielectric properties of adsorbent materials., ${ }^{3,4,7}$

In this study, silicon carbide material was employed as the adsorbent for the microwave assisted catalytic gasification. ${ }^{7}$ The critical efficiency of converting microwaves to thermal energy using silicon carbide adsorbent material was predicted using a dielectric constant of $34 \% .^{3,4}$ With reference to the weight and volume of compact energy systems built around conventional gasification, the addition of a magnetron to the gasification

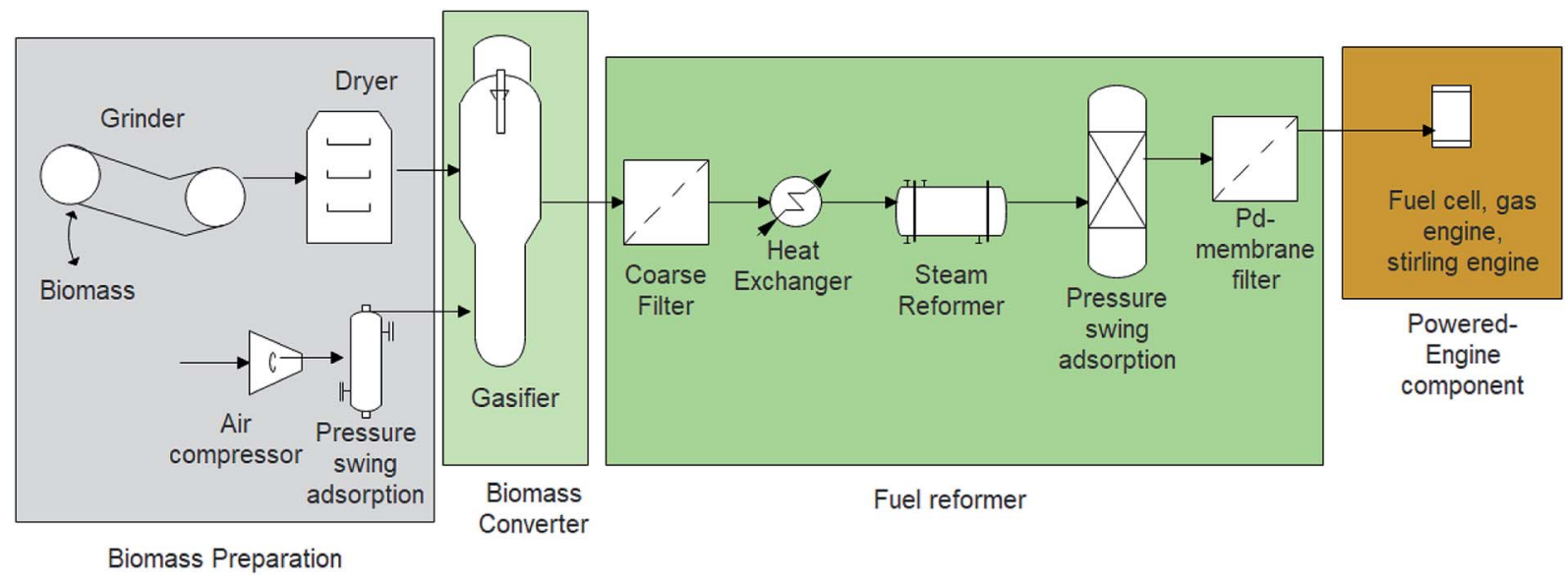

Fig. 2 General schematic of compact energy system built around biomass gasification. 
Table 4 Different types of compact energy systems built around various gasification technologies

\begin{tabular}{|c|c|c|c|c|c|c|c|c|c|c|c|c|c|c|c|}
\hline \multirow{2}{*}{$\begin{array}{l}\text { Biomass converter technology } \\
\text { Powered-engine } \\
\text { Food waste }\end{array}$} & \multicolumn{3}{|c|}{$\begin{array}{l}\text { Conventional } \\
\text { gasification }\end{array}$} & \multicolumn{3}{|c|}{$\begin{array}{l}\text { Catalytic } \\
\text { gasification }\end{array}$} & \multicolumn{3}{|c|}{$\begin{array}{l}\text { Steam } \\
\text { gasification }\end{array}$} & \multicolumn{3}{|c|}{$\begin{array}{l}\text { Supercritical } \\
\text { gasification }\end{array}$} & \multicolumn{3}{|c|}{$\begin{array}{l}\text { Microwave assisted } \\
\text { gasification }\end{array}$} \\
\hline & G & $\mathrm{S}$ & $\mathrm{F}$ & G & $\mathrm{S}$ & $\mathrm{F}$ & $\mathrm{G}$ & $\mathrm{S}$ & $\mathrm{F}$ & G & $\mathrm{S}$ & $\mathrm{F}$ & G & $\mathrm{S}$ & $\mathrm{F}$ \\
\hline Lignocellulose & $\mathrm{X}$ & $\mathrm{X}$ & $\mathrm{X}$ & $\mathrm{X}$ & $\mathrm{X}$ & $\mathrm{X}$ & $\mathrm{X}$ & $\mathrm{X}$ & $\mathrm{X}$ & & & & $\mathrm{X}$ & $\mathrm{x}$ & $\mathrm{X}$ \\
\hline Grinder & $\mathrm{X}$ & $\mathrm{X}$ & $\mathrm{x}$ & $\mathrm{x}$ & $\mathrm{x}$ & $\mathrm{X}$ & $\mathrm{x}$ & $\mathrm{X}$ & $\mathrm{x}$ & $\mathrm{x}$ & $\mathrm{X}$ & $\mathrm{x}$ & $\mathrm{x}$ & $\mathrm{x}$ & $\mathrm{X}$ \\
\hline Dryer & $\mathrm{X}$ & $\mathrm{X}$ & $\mathrm{X}$ & $\mathrm{X}$ & $\mathrm{X}$ & $\mathrm{X}$ & $\mathrm{X}$ & $\mathrm{X}$ & $\mathrm{X}$ & & & & $\mathrm{X}$ & $\mathrm{X}$ & $\mathrm{X}$ \\
\hline Gasifier & $\mathrm{X}$ & $\mathrm{X}$ & $\mathrm{X}$ & $\mathrm{X}$ & $\mathrm{X}$ & $\mathrm{X}$ & $\mathrm{X}$ & $\mathrm{X}$ & $\mathrm{X}$ & $\mathrm{X}$ & $\mathrm{X}$ & $\mathrm{X}$ & $\mathrm{X}$ & $\mathrm{X}$ & $\mathrm{X}$ \\
\hline Steam reformer & $\mathrm{X}$ & $\mathrm{x}$ & $\mathrm{X}$ & $\mathrm{x}$ & $\mathrm{x}$ & $\mathrm{X}$ & $\mathrm{x}$ & $\mathrm{x}$ & $\mathrm{X}$ & & & & $\mathrm{x}$ & $\mathrm{x}$ & $\mathrm{X}$ \\
\hline Heat exchanger & $\mathrm{X}$ & $\mathrm{x}$ & $\mathrm{x}$ & $\mathrm{x}$ & $\mathrm{x}$ & $\mathrm{X}$ & $\mathrm{x}$ & $\mathrm{x}$ & $\mathrm{x}$ & $\mathrm{X}$ & $\mathrm{x}$ & $\mathrm{X}$ & $\mathrm{x}$ & $\mathrm{X}$ & $\mathrm{X}$ \\
\hline Coarse filter & $\mathrm{X}$ & $\mathrm{X}$ & $\mathrm{X}$ & $\mathrm{X}$ & $\mathrm{X}$ & $\mathrm{X}$ & $\mathrm{X}$ & $\mathrm{X}$ & $\mathrm{X}$ & $\mathrm{X}$ & $\mathrm{X}$ & $\mathrm{X}$ & $\mathrm{X}$ & $\mathrm{X}$ & $\mathrm{X}$ \\
\hline PSA for syngas purification & & & $\mathrm{X}$ & & & $\mathrm{X}$ & & & $\mathrm{X}$ & & & & & & $\mathrm{X}$ \\
\hline Pd-membrane & & & $\mathrm{X}$ & & & $\mathrm{X}$ & & & $\mathrm{X}$ & & & $\mathrm{X}$ & & & $\mathrm{X}$ \\
\hline
\end{tabular}

reactor increases the weight and volume by $5 \%$ and $10 \%$ respectively. The weight and volume dimensions of a magnetron can be found in Obata $e t$ al. ${ }^{8}$

The comparison of amounts of hydrogen and producer gas delivered by different compact energy system types (T1 to T9) indicates that high hydrogen/producer gas yield per unit of dry biomass can be varied with the type of biomass gasification technology. The variance is attributed to the different carbon, hydrogen, and oxygen compositions of the biomass (Table S1†), different gasification operating conditions like temperature (Table S2 $\dagger$ ), hydrogen production yields in the gasifier, and the amount of moisture present in the biomass at the gasification reactor stage.

Among the compact energy system types $\mathrm{T} 1$ to $\mathrm{T} 9$, the net available energy in terms of kilowatt-hours produced by the compact energy system with a fuel cell as a power engine component is higher than that of gas and Stirling engines
(Table 5). This is because the fuel cell efficiency of converting hydrogen to net available energy compared to the efficiency of converting hot gas to net available energy in Stirling engines is much higher (Table S3†). The weight and volume of compact energy systems with a Stirling or gas engines is found to be higher than that of a compact energy system with a fuel cell as the power engine component (Table 3). For the same reasons, high fuel efficiency, easy separation of hydrogen, and low specific power and power density, the compact energy system with a hydrogen fuel cell component is found to have a high specific power $\left(\mathrm{W} \mathrm{kg}^{-1}\right)$ and volumetric power density $\left(\mathrm{W} \mathrm{L}^{-1}\right)$ compared to a gasoline or Stirling engine (Fig. 3).

\subsection{Hydrogen storage}

The compact energy applications may demand hydrogen storage. The lower pressure hydrogen storage can be accomplished with adsorption on metal hydrates or with chemical

Table 5 Weight, volume, and net energy of different types of compact energy systems

\begin{tabular}{|c|c|c|c|c|c|c|c|}
\hline $\mathrm{T} 2$ & 14 & 10 & $16.5(\mathrm{P})$ & 10.7 & 0.45 & 15 & 37 \\
\hline $\mathrm{T} 3$ & 14 & 10 & $1(\mathrm{H})$ & 13.3 & 0.56 & 8 & 5 \\
\hline $\mathrm{T} 4$ & 19 & 10 & $23(\mathrm{P})$ & 9.2 & 0.38 & 6.3 & 39 \\
\hline $\mathrm{T} 7$ & 24 & 10 & $23.5(\mathrm{P})$ & 6.9 & 0.29 & 7 & 33 \\
\hline $\mathrm{T} 8$ & 24 & 10 & $23.5(\mathrm{P})$ & 7.4 & 0.31 & 14 & 32 \\
\hline T9 & 24 & 10 & $1.2(\mathrm{H})$ & 11.7 & 0.49 & 7.35 & 5 \\
\hline $\mathrm{T} 10$ & 70 & 10 & $60(\mathrm{P})$ & -15.5 & -0.65 & 14 & 59 \\
\hline $\mathrm{T} 11$ & 70 & 10 & $60(\mathrm{P})$ & -14 & -0.58 & 24 & 44 \\
\hline $\mathrm{T} 12$ & 70 & 10 & $0.3(\mathrm{H})$ & -7.5 & -0.31 & 12 & 11 \\
\hline
\end{tabular}

${ }^{a}$ Net power is calculated assuming operational time of 24 hours. 


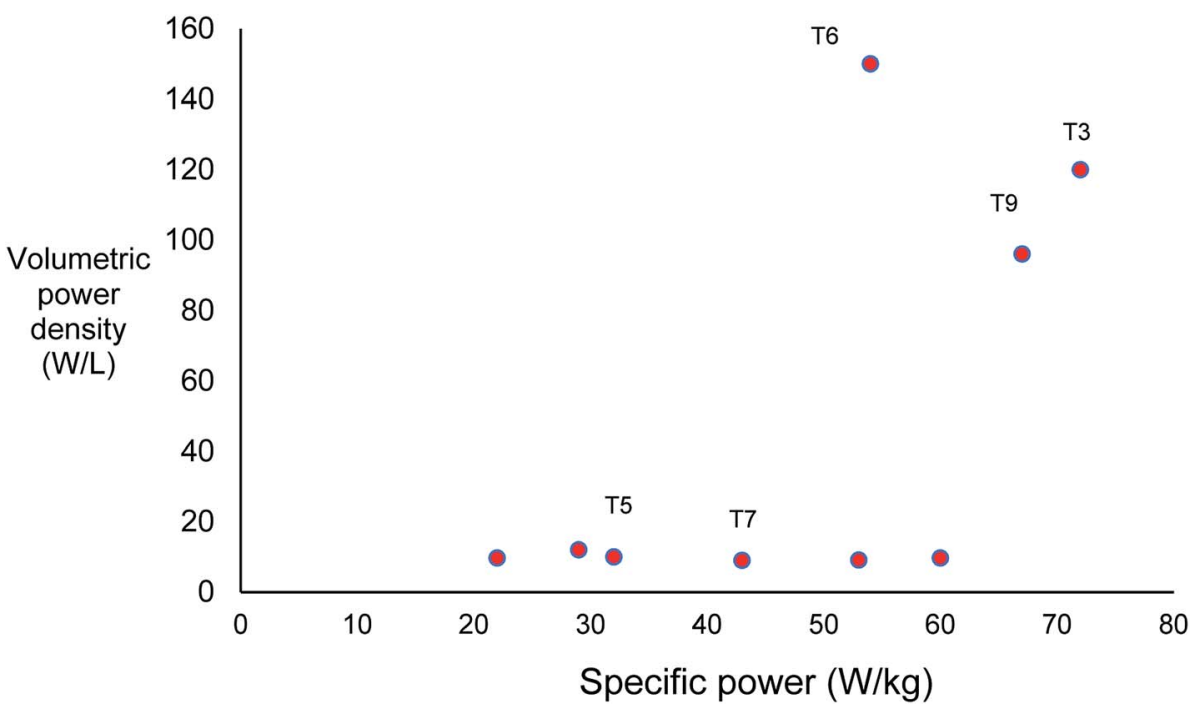

Fig. 3 The comparison of volumetric power density and specific power of different compact energy system types.

binding. ${ }^{19}$ Hydrogen can be compressed to a high pressure (>3500 PSI) to store in a tank. ${ }^{19}$ Hydrogen may also be stored via liquefaction. ${ }^{19}$ Among different storage techniques, compressed hydrogen technology offers low system weight and volume in addition to a low energy requirement. ${ }^{19}$ The necessary energy to compress the hydrogen and physical dimensions (weight and volume) of the compressor vary with the compressor technology and the target compression ratio. ${ }^{20}$ of existing hydrogen compression technologies, the electrochemical hydrogen compressor (EHC) technology is found to be a viable candidate for hydrogen compression at a compact scale due to its simple compression principle. ${ }^{20}$ Liquefaction requires approximately 4 $\mathrm{kW}$ h to compress the hydrogen to 5000 PSI from 72 PSI (the pressure at which hydrogen leaves from Pd-membrane unit) using the an EHC. The estimated weight (kg) of the EHC with a capacity of $1 \mathrm{~kg}$ per day and a hydrogen storage tank with a capacity of $1 \mathrm{~kg}$ are 100 and 39 respectively. The addition of an EHC and hydrogen storage tank to the T3, T6, and T9 compact energy systems decrease their net available energy by $30 \%$, increase their weight by $2000 \%$, and reduce their specific weight by $94 \%$. Such a heavy weight in a compact energy system with a low specific power may limit its application to charging purposes at refueling stations. To use compact energy systems with a hydrogen storage module as an on-board power source for manned and unmanned vehicles, the development of a new, lightweight, hydrogen compression technology is necessary.

\subsection{Sensitivity to power requirement}

The weight of a compact energy system can be dependent on the target power output and operational time as these parameters influence the amount of biomass processed by the compact energy system per unit time. Thus, the weight of a compact energy system built around catalytic gasification (T6) is calculated for a range of target power output values and operational times. These results are also applicable to T3 and T9 compact energy systems because the volumetric power density and specific power of T3, T6, and T9 compact energy systems are nearly same (Fig. 3). The weight of a compact energy systems without the requirement of a hydrogen compressor is computed for a range of operating times and output power requirements (Fig. 4). Since it is difficult to visualize Fig. 4, the results to generate Fig. 4 are presented in Table S4. $\dagger$

Fig. 4 shows that for a given power requirement, the weight of a compact energy system increases with operational time. Similarly, for a given operational time, the weight of compact energy systems increases with the target power output. Such an increase in the weight of compact energy systems is attributed to the increase in the biomass flow rate. Fig. 4 or Table $\mathrm{S} 4 \dagger$ can be used to determine the viability of deploying compact energy systems built around gasification to supply target power for the manned and unmanned ground vehicles. For instance, the Clearpath's Husky Unmanned Ground Vehicle has a power requirement of $1 \mathrm{~kW}$ with an operational time of 3 hours. These requirements can be met with the compact energy system types of T3, T6, and T9 with a weight of $4.4 \mathrm{~kg}$. Since the maximum payload of the Husky Unmanned Ground Vehicle is about $70 \mathrm{~kg}$, it is viable to deploy compact energy systems built around catalytic gasification for providing system power.

\subsection{Opportunities}

In this section we highlight the challenges and opportunities with the compact energy system built around gasification. The comparison of total weights of compact energy system types T3, T6, and T9 show that compact energy systems built around catalytic gasification have higher weights than that of the other two because of heavy weight requirements of hydrogen purification. Though the hydrogen separation scheme employed is similar in all three compact energy system types, the large water content of biomass derived syngas using catalytic gasification results in a large weight of T6 compact energy systems.

The steam reformed syngas consists of significant trace amounts of impurities. These impurities include water, carbon 


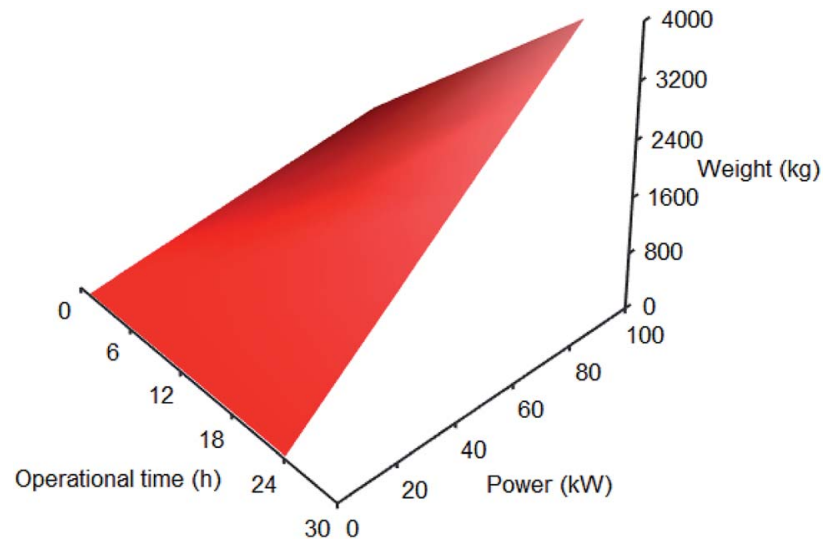

Fig. 4 The weight $(\mathrm{kg})$ of compact energy system built around gasification for the target power (kW) and operational time (h).

monoxide, carbon dioxide, and $\mathrm{H}_{2} \mathrm{~S}$. These impurities can be removed, and hydrogen, with a purity of $>99 \%$, can be produced using the pressure swing adsorption followed by the Pdmembrane separation. The hydrogen purification system weight can be reduced, and the energy efficiency can be improved through process intensification, i.e. by combining two-unit processes to one-unit process. We propose such process intensification for hydrogen purification using the compact Pd-membrane process. In this compact process, the traditional Pd-membrane is modified by having a layer of zeolite (aluminosilicate framework $\mathrm{Al}_{2} \mathrm{O}_{3} / \mathrm{SiO}_{2}$ ) with an activated carbon deposition on top of the Pd-membrane. The deposited carbon can adsorb water and the silica zeolite can adsorb $\mathrm{H}_{2} \mathrm{~S}$ and CO. Research is necessary to create a compact Pdmembrane process for studying its performance in purifying hydrogen from the steam reformed syngas.

In this study, we assumed that the biomass moisture can be removed by supplying heat via hot syngas using a compact heat exchanger (refer ESI $\dagger$ for more information about modeling details). Compact heat exchangers for the heat transfer between gas-gas, gas-liquid, as well as liquid-liquid mediums have been used in real-life applications. ${ }^{21}$ Although implemented commercially, compact heat exchangers for heat transfer between solid biomass and hot gas need to be further developed for industrial applications. Additionally, further research is needed to identify materials with a high enough specific heat conductivity to withstand temperatures greater than $1000{ }^{\circ} \mathrm{C}$ for use as tube material.

The individual components of compact energy system types T3, T6, and T9 were demonstrated at various scales independently. However, the compact unit processes within each component as individual components have not yet been integrated to one holistic system to produce energy. Further work is necessary to build a prototype that integrates individual components and their respective unit processes. The development of the prototype should progress through several design iterations, implementing inexpensive materials. Like the compact energy systems with the gasification as the biomass converter technology, future work is necessary to determine the feasibility of developing compact energy systems listed in Tables 1 and 3. Additionally, the unit processes within the individual components of compact energy systems listed in Tables 1 and 3 must be studied to reduce the size and weight of the process equipment and improve the energy efficiency. For instance, the blue whirl combustion technology listed in Tables 1 and 3 is still at the technology readiness level of one and it is currently studied to understand the physical and chemical aspects responsible for the formation of blue whirl for the transition of this new combustion technology to a higher technology readiness level. ${ }^{22}$

\section{Conclusions}

Compact energy systems with catalytic, steam, and conventional gasification as biomass converter technologies are found to be more energy efficient, light weight, and of a smaller size than that of microwave assisted or super-critical gasification technologies. The use of a fuel cell as a powered-engine component is more optimal in terms of energy, size, and weight than that of a Stirling engine compact energy system built around gasification. Due to the heavy weight of an electrochemical hydrogen compressor, the integration of a hydrogen storage module is viable only when these energy systems are used for charging applications.

Innovations for process intensification for syngas separation and purification processes can further reduce the size and increase the energy efficiency of systems built around gasification. The successful integration of the individual components of compact energy systems with biomass gasification as the upgrading pathway can increase the energy security, operation, and reduce the environmental impacts associated with the production of petroleum derived energy. Furthermore, successful integration can reduce capital risks and logistic challenges associated with the production of energy in a large scale biorefinery with a dry biomass processing capacity on the order of $10^{\circ}$ to $10^{3}$ metric tons per day. Like this study, system analysis of compact energy systems with fermentation and pyrolysis as biomass upgrading pathways must be performed to determine the viability of respective compact energy systems for power applications.

\section{Conflicts of interest}

There are no conflicts to declare.

\section{Acknowledgements}

The authors thank David M. Mackie for participating in various discussions related to the development of compact energy systems development at the U.S. Army Research Lab. Research was sponsored by the U.S. Army Research Laboratory and was accomplished under Cooperative Agreement Number W911NF16-2-0008. The views and conclusions contained in this document are those of the authors and should not be interpreted as representing the official policies, either expressed or implied, of the U.S. Army Research Laboratory or the U.S. Government. The 
U.S. Government is authorized to reproduce and distribute reprints for Government purposes notwithstanding any copyright notation herein.

\section{References}

1 R. D. Perlack and B. J. Stokes, U.S. Billion-Ton Update: Biomass Supply for a Bioenergy and Bioproducts Industry, United States Department of Energy, 2011, ORNL/TM-2011/ 224.

2 D. Humbird, R. Davis, L. Tao, C. Kinchin, D. Hsu, A. Aden, P. Schoen, J. Lukas, M. Worley, D. Sexton and D. Dudgeon, Process design and economics for biochemical conversion of lignocellulosic biomass to ethanol-Dilute acid pretreatment and enzymatic hydrolysis of corn stover, National Renewable Energy Laboratory, 2011, NREL/TP-5100-47764.

3 S. Jones, P. Meyer, L. Snowden-Swan, A. Padmaperuma, E. Tan, A. Dutta, J. Jacobson and K. Cafferty, Process Design and Economics for the Conversion of Lignocellulosic Biomass to Hydrocarbon Fuels: Fast Pyrolysis and Hydrotreating Biooil Pathway, National Renewable Energy Laboratory, 2013, NREL/TP-5100-61178.

4 T. Richards, Challenges in Scaling Up Biofuels Infrastructure, Science, 2010, 329, 793-796.

5 S. Gunukula, A. Daigneault, A. A. Boateng, C. A. Mullen, W. J. DeSisto and M. C. Wheeler, Influence of Upstream, Distributed Biomass-Densifying Technologies on the Economics of Biofuel Production, Fuel, 2019, 249, 326-333.

6 A. Ramachandra, Performance Studies on a Wood Gas Run I.C. Engine, 4th National meeting, Recent advances in biomass gasification and combustion, India, 1993.

7 K. Adepu and S. Shaishav, Recent updates on different methods of pretreatment of lignocellulosic feedstocks: a review, Bioresources and Bioprocessing, 2017, 4, 7.

$8 \mathrm{H}$. Obata, K. Furumoto and H. Miyamoto, State of the Art Advanced Magnetrons for Accelarator RF Power Source, Proceedings of 28th Linear Accelerator Conference, 2016.

9 E. Pereira, J. da Silva, J. de Oliveira and C. Machado, Sustainable energy: a review of gasification technologies, Renewable Sustainable Energy Rev., 2012, 16, 4753-4762.
$10 \mathrm{~V}$. Dhyani and T. Bhaskar, A comprehensive review on the pyrolysis of lignocellulosic biomass, Renewable Energy, 2018, 129, 695-716.

11 A. Kang and T. Lee, Converting Sugars to Biofuels: Ethanol and Beyond, Bioengineering, 2015, 2, 184-203.

$12 \mathrm{M}$. Elshahed, Microbiological aspects of biofuel production: current status and future directions, J. Adv. Res., 2010, 1, 103-111.

13 H. J. Alves, Overview of hydrogen production technologies from biogas and the applications in fuel cells, Int. J. Hydrogen Energy, 2013, 38, 5215-5225.

$14 \mathrm{Z}$. Dunbar, Hydrogen purification of synthetic water gas shift gases using microstructured palladium membranes, J. Power Sources, 2015, 297, 525-533.

15 N. Querejeta, Carbon monoliths in adsorption-based postcombustion $\mathrm{CO}_{2}$ capture, Energy Procedia, 2017, 114, 23412352.

16 G. Sridhar, Development of producer gas engines, Proc. Inst. Mech. Eng., Part D, 2004, 219(3), 423-438.

17 J. G. Wood and N. Lane, Advanced 35 W Free-Piston Stirling Engine for Space Power Applications, Sunpower Inc, 2003.

18 A. Kirubakaran, S. Jain and R. Nema, A review on fuel cell technologies and power electronic interface, Renewable Sustainable Energy Rev., 2009, 13, 2430-2440.

19 R. M. Gardiner and A. Burke, Comparison of hydrogen storage technologies: a focus on energy required for hydrogen input, Fuel Chemistry Division Preprints, 2002, vol. 47, p. 794.

20 P. Bouwman, Electrochemical Hydrogen Compression (EHC) solutions for hydrogen infrastructure, Fuel Cells Bull., 2014, 214, 12-16.

21 D. Reay, A. Harvey and C. Ramshaw, Process Intensification: Engineering for Efficiency, Sustainability and Flexibility, Elsevier Science \& Technology, 2013.

22 H. Xiao, M. J. Gollner and E. S. Oran, From fire whirls to blue whirls and combustion with reduced pollution, Proc. Natl. Acad. Sci. U. S. A., 2016, 113, 9457-9462. 